- SWANA represents the interest of its membership before legislative and regulatory bodies.

- SWANA develops and advocates policies in the field of municipal solid-waste management.

- SWANA is a member of the International Solid Waste and Public Cleansing Association (ISWA). Through this mechanism, SWANA provides a means for its membership to interact with their peers in other countries.

SWANA services are available to anyone working in the field of MSWM, or to any individual who is interested in the subject of MSWM. Most services are available at little or no cost, but SWANA members receive a discount for all services for which there is a charge. For further information please contact the undersigned.

H. LANIER Hickman, Jr, Executive Director

Solid Waste Association of North America (SWANA)

8750 Georgia Avenue, Suite 140

PO Box 7219

Silver Spring

Maryland 20910-7219, USA.

Tel. 301-585-2898; Fax 301-589-7068

\title{
International Wilderness Leadership (WILD) Foundation
}

$\mathrm{T}_{\mathrm{F}}^{\text {he }}$ he International Wilderness Leadership (WILD) Foundation is now doing business as the WILD Foundation. The original name has been in use since 1974 and will continue to serve as the organization's full legal name. However the new, easy-to-remember name has been established for more popular use.

The mission of the WILD Foundation remains the same: developing and supporting projects that link wilderness and people. This is accomplished through the protection of wilderness and wildlife, the promotion of the wise use of wildlands world-wide, and the provision of environmental education and training. The Foundation works internationally through an active Board of Directors, associates in the field, and local governmental and nongovernmental conservation organizations.

WILD has a special focus on wilderness and people issues in southern Africa. For example, in Botswana, the focus is on training, education, and resolving critical issues in the Okavango Delta. The Foundation has provided a patrol aircraft to be used in the Zambezi Valley in Zimbabwe to help control poaching and assist in translocating the Black Rhino (Diceros bicornis). WILD supports the Cheetah Conservation Fund in Namibia, where two skilled research workers are striving to save the Cheetah (Acinonyx jubata) from extinction. WILD also works in South Africa to develop environmental education, wilderness designation, wilderness experience, and training programmes. In Mozambique, WILD is helping to supply equipment for the new Bazaruto Archipelago National Park.

The WILD Foundation is probably best known for periodically convening the World Wilderness Congress (WWC). The Congress, an ongoing international, action- oriented forum, has so far convened on four occasions (South Africa, 1977; Australia, 1980; Scotland, 1983; and United States, 1987), and has involved thousands of delegates from more than 70 countries. From throughout the world, politicians, corporate executives, scientists, teachers, tribal people, philosophers, and the general public, meet to discuss - and act on - issues and projects involving wilderness, world-wide conservation, and sustainable development. The 5th WWC is earmarked to convene in Norway in September 1993 and will focus on wild Nature and sustainable living in the circumpolar regions. The celebrated Norwegian explorer and conservationist Dr Thor Heyerdahl, of Kon Tiki fame, will serve as the Honorary Chairman.

The WILD Foundation also produces books, their most recent to appear, published in cooperation with the US Forest Service, being the second edition of Wilderness Management, which is the major sourcebook in this field. The Foundation's newsletter, the Leaf, is published three times per year ( $\$ 20$ subscription); it serves to review the status of WILD's programmes and to provide an experienced perspective on critical international conservation issues.

\section{VANCE G. MARTIN, President International Wilderness Leadership (WILD) Foundation \\ 211 West Magnolia Street \\ Fort Collins \\ Colorado 80521 \\ USA.}

Tel. (303) 498-0303

Fax: (303) 498-0403

\section{Biological 'Hotspots' Face Most Serious Threats}

$\mathrm{R}$ ain-forest 'hotspots', containing the planet's greatest diversity of plant and animal species, also face the greatest threat of deforestation. Moreover they are located in countries which are among the least prepared economically and scientifically - to conserve their biological resources, according to a document recently published by Conservation International, a non-profit organization based in Washington, DC, USA. This document is in the form of a large and coloured, three-timesfolded poster entitled Biodiversity at Risk: A Preview of Conservation International's Atlas for the 1990s. Priced at US \$9.95, it combines for the first time data on biological richness, human disturbance, and local conservation capacity, in virtually all of the world's nations, including those that harbour 15 rain-forest 'hotspots' and 3 tropical wilderness areas. Rain-forest 'hotspots' are considered the most diverse and most threatened on Earth.

The data on the large poster are displayed on a series of maps and maplets produced by Conservation International's geographic information system (CI/SIG), a computer programme that allows researchers to integrate biological and ecological data with socio-economic and physical-environment data. New data on human disturbance reveal that more than half the world's land-area has been changed from its natural state, and show that the majority of Earth's richest habitats have been already altered significantly by human intervention. With the exception of tropical and cold deserts and polar tundra, the 
only large, relatively pristine wilderness areas are in the tropics.

'The data collected here - particularly the newlyassembled information on human disturbance to the planet - convey a critical message' says Conservation International's President Russell A. Mittermeier. 'Maintaining our remaining tropical ecosystems and their wealth of plant and animal species is one of today's most important conservation challenges.'

Because every species-extinction represents an irreversible loss, precisely locating areas of high biological diversity is critical. Four of the maplets in Biodiversity at Risk depict the relative numbers of species of birds, mammals, reptiles, and amphibians, by country. Chosen because they are the main animal groups for which pertinent information on distribution is available, these species reflect overall patterns of diversity - and dramatically illustrate that the highest concentration of biodiversity lies in key areas in certain tropical nations. But comparing biodiversity distribution maps with maps displaying data on conservation capacity, reveals a serious gap in human resources, namely that of the countries which are richest in species being the least technically prepared to protect them.

Measured in terms of natural science students and herbarium specimens - the biologists and stored plant materials that are needed to assess a region's biodiversity - two of the maps in Biodiversity at Risk show that developing countries in Africa, Asia, and Latin America, fall far short of industrialized nations. As an example, one of the maps shows that Bolivia — which ranks high on all four biodiversity maplets - has only a handful of postsecondary-school natural science students. In 1990, a Conservation International-sponsored Rapid Assessment Program (RAP) team uncovered an extraordinary level of biodiversity in an unexplored Bolivian rain-forest near the Peruvian border. Officials immediately recommended that the area, known as Alto Madidi, be protected by the government. It had been overlooked before because Bolivia's few, overworked field biologists had not had an opportunity to survey the area.

Another example is Madagascar, considered one of the world's top three endangered 'hotspots'. Although Madagascar has an estimated 8,000 to 10,000 different plant species - about $80 \%$ of them found nowhere else on Earth - it has fewer than 10 herbarium specimens for each species in the country. By contrast Great Britain, which has only a fraction of the number of plant species possessed by Madagascar, has an average of 1,000 or more dried herbarium specimens per species.

'The first step in protecting biodiversity is scientific research: studying [individual ecosystems and their aggregations into wider ecocomplexes as well as] their species - and identifying threats to their survival - is the foundation of conservation,' says President Mittermeier. 'What we need is a global conservation corps, with each country making a national priority of training conservationists and providing the technology and resources [that are] needed to study and protect its own biological wealth.'

Conservation International's strategy of ecosystem and ecocomplex conservation includes a major focus on cultivating local conservation capacity in countries that are home to the planet's greatest and most threatened biodiversity. The organization works to build conservation capacity in developing countries through financial and technical support to local communities, private concerns, and government agencies.

LAURA TANGLEY
Conservation International
1015 18th Street NW, Suite 1000
Washington
DC 20036, USA.

LAURA TANGLEY 101518 th Street NW, Suite 1000 DC $20036, U S A$.

\section{Nature Conservation in Central and Eastern Europe: the Time for Change and Hope*}

$T^{\text {he }}$ The fall of authoritarian political regimes in central and eastern Europe has introduced new uncertainties but also new hopes for Nature conservation on the continent. The mismanagement of natural resources is a common feature of dictatorial forms of government, where public opinion cannot influence development or conservation policies. Thus vast areas have been severely polluted, cities have grown tremendous and ugly, rivers have been transformed into open-air sewers, and intensive agriculture and land consolidation have flattened and simplified otherwise colourful and diverse rural landscapes.

The results of eastern Europe's ageing industry, and the lack of the most elementary pollution-control standards, have been widely publicized. Yet the irrationality of authoritarian policies has also left vast parts of the territories of those states virtually untouched in the past 40 years, receiving little or no exploitation. This means that, not far from heavily polluted areas, we still find almost pristine mountains and well-preserved forests with interesting animal species, such as the Brown Bear (Ursus arctos), the Wolf (Canis lupus), and the Lynx (Lynx

* Based on the account in Naturopa-Newsletter, Special Issue on the Bern Convention, Nr 3, 1992. - Ed. $l y n x)$, which are practically absent from western Europe. The Russian steppes, the Balkans, the Carpathian mountains, and the River Danube, all contain ecosystems and wider ecocomplexes of the highest importance for the conservation of Europe's natural values. It is a shared responsibility of all Europeans to preserve their rich heritage.

\section{Coming Years Critical}

The next years will be critical for the future of wildlife in central and eastern Europe. There will be in this region a very logical trend towards economic development, which may affect wilderness areas drastically. As the economic situation improves, new roads, dams, and industries, will be built, tourism will develop in rural areas, and hunting, agriculture, and forestry, will undergo deep changes. The real challenge will be to control and direct 'market forces' so that they respect the beauty and interest of the natural areas - a task which has to be contemplated on a pan-European scale. Thus the answer lies in wise sustained development and international cooperation. These are the ideas behind the Convention on the Conservation of European Wildlife and Natural Habitats, better known as the 'Bern Convention'. 